\title{
ON AN ACUTE CASE OF CHAGAS DISEASE IN A REGION UNDER VECTOR CONTROL IN THE STATE OF SÃO PAULO, BRAZIL
}

\author{
Dalva M.V. WANDERLEY(1), Vera L.C.C. RODRIGUES(1), Ruth Moreira LEITE(2), Sueli Yasumaro DIAZ(1), Maria Esther de CARVALHO(1), \\ Soraya O. SANTOS(3), Érica TATTO(3), Maria Salete CARLI(4), Kunie I.R. COELHO(5), Paulo Ribeiro da SILVA(1), Sandra Aparecida TÚLIO(4), \\ Isaias Ribeiro da SILVA(1) \& Maria A. SHIKANAI-YASUDA(6)
}

\begin{abstract}
SUMMARY
No vector transmitted cases of Chagas disease had been notified in the state of São Paulo since the 1970s. However, in March, 2006, the death of a six-year-old boy from the municipality of Itaporanga was notified to the Center for Epidemiological Survey of the São Paulo State Health Secretariat: an autochthonous case of acute Chagas disease. The postmortem histopathological examination performed in the Hospital das Clínicas of the Botucatu School of Medicine confirmed the diagnosis. Reference to hospital records, consultation with the health professionals involved in the case and interviews with members of the patient's family supplied the basis for this study. We investigated parasite route of transmission, probable local reservoirs and vectors. No further human cases of acute Chagas disease were diagnosed. No locally captured vectors or reservoirs were found infected with Trypanosoma cruzi. Alternative transmission hypotheses - such as the possible ingestion of foods contaminated with vector excreta - are discussed, as well as the need to keep previously endemic regions and infested houses under close surveillance. Clinicians should give due attention to such signs as uni- or bilateral palpebral edema, cardiac failure, myocarditis, pericarditis, anasarca and atypical signs of nephrotic syndrome or nephritis and consider the diagnostic hypothesis of Chagas disease.
\end{abstract}

KEYWORDS: Acute Chagas disease; Clinical features; State of São Paulo, Brazil.

\section{INTRODUCTION}

No vector transmission of Chagas disease (CD) had been notified to the health authorities of the state of São Paulo since the mid 1970s ${ }^{9}$. Over the last thirty years the Control Program of the Superintendência de Controle de Endemias - SUCEN (Superintendency for the Control of Endemic Diseases) has been adjusting its actions according to the extent of home triatomine infestation. Thus, the areas marked out for active vector search had been gradually restricted. Active vector search was finally discontinued in the year 2002. At the same time investment in the educational part of the Control Program was supplemented, aiming to stimulate residents in rural zones and the outskirts of cities under surveillance to notify the occurrence of suspected insects in their homes. Accordingly, they are now partaking in the work of $\mathrm{CD}$ prophylaxis. Surveillance posts were installed to collect and identify the insects captured by local residents ${ }^{13}$.

As it has been a rare occurrence in the state of São Paulo for at least three decades, acute Chagas disease (ACD) can now be a diagnostic challenge for those general medical practitioners who are not familiar with its signs and symptoms. Indecision and the consequent lack of prompt diagnosis tend to delay or even prevent the prescription of specific treatment. Concerning epidemiological surveillance, the identification of an isolated occurrence is as important as that of an outbreak or an accidental laboratory contamination: immediate control measures are required.

In March 2006 a lethal case of ACD - a six-year-old boy from the municipality of Itaporanga - was notified to the Center for Epidemiological Surveillance of the São Paulo State Health Secretariat, or Centro de Vigilância Epidemiológica da Secretaria de Estado da Saúde de São Paulo (CVE-SP). Postmortem examination had established the diagnosis of his condition. The municipality of Itaporanga is included in the XVI ${ }^{\text {th }}$ Botucatu Regional Health Section. An investigation into the case was initiated by a team which included epidemiological surveillance technicians from: the municipality of Itaporanga, branches of SUCEN based in the municipalities of Sorocaba, Itararé, São Paulo and Mogi Guaçu, XVI ${ }^{\text {th }}$ Botucatu Health Regional Section, Epidemiological Surveillance Group based in the municipality of Avaré, and CVE-SP. The task of investigating mode of transmission, reservoirs, and vectors involved was assigned to a multi-professional team from central and local administrative levels.

(1) Superintendência de Controle de Endemias-SUCEN/SES/São Paulo, SP, Brasil 


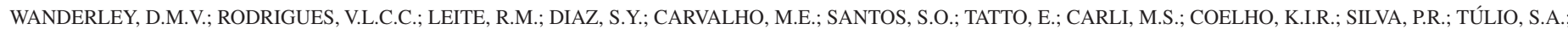
SILVA, I.R. \& SHIKANAI-YASUDA, M.A. - On an acute case of Chagas disease in a region under vector control in the State of São Paulo, Brazil. Rev. Inst. Med. Trop. Sao Paulo, 52(3):151-6, 2010.

\section{MATERIALS AND METHODS}

We analyzed information kept in the records of the institutions where the patient had received medical care, both as an outpatient and as an inpatient, in Itaporanga, Avaré and Botucatu. We describe the consequent epidemiological and entomological investigation, which involved a search for triatomine vectors and potential vertebrate reservoirs in the area. We made house calls and had talks with members of the patient's family. From his parents, both his brothers and his grandmother (who lives in another house) blood samples were collected for the serological tests: immunofluorescent antibody test (IFAT) and Enzyme-Linked ImmunoSorbent Assay (ELISA) for the diagnosis of Chagas disease, which were performed as specified by the kit manufacturers (Immunocom, WAMA diagnóstica and Test ELISA para Chagas - BIOSChile respectively). Triatomines and vertebrate reservoirs were searched for inside and outside the house and in the annexes. Dislodging agents were applied before insecticide spraying. Light traps ${ }^{7}$ to capture adult triatomines and traps intended for synanthropic as well as wild potential vertebrate Trypanosoma cruzi reservoirs were also set up on the premises ${ }^{10}$. Fluid extracted by abdominal compression from the captured triatomines was used to prepare both May-Grünwald/Giemsa stained smears to be examined for trypanosomes ${ }^{10}$ and precipitin blood meal identification tests ${ }^{12}$. Giemsa stained ${ }^{10}$ blood smears from the captured synanthropic and wild animals were also examined for trypanosomes. Xenodiagnosis, using 10 insect specimens (Triatoma infestans and Panstrongylus megistus $4^{\text {th }}$ and $5^{\text {th }}$ nymphal stages) was another diagnostic technique applied to this case.

\section{RESULTS}

1. Clinical investigation: A six-year-old male was taken to an out-patient clinic in Itaporanga on February $8^{\text {th }}, 2006$. He had nausea, hyporexia, and cephalea. Diagnostic hypotheses: upper respiratory tract infection (URTI) and helminthiasis. Ceftriaxone was prescribed and administered accordingly. February $11^{\text {th }}, 2006$ : new consultation, this time at Nossa Senhora das Graças Hospital in Itaporanga. Observed: fever, edema, and abdominal pain. Prescribed: Dipirone and Dimethicone. February $13^{\text {th }}, 2006$ : no health improvement. The patient was taken for further consultation. Diagnosis: pharyngitis. Chest radiography failed to show any heart or lung problem (eventually identified in Avaré and Botucatu). February $15^{\text {th }}$, 2006: emergency consultation in Itaporanga. Requested: chest radiography. Diagnosis: pneumonia. The patient was febrile; chest radiography showed a paracardiac effusion on the right side and enlargement of the cardiac area. Treatment with Ceftriaxone was maintained.

Thirteen days after the first consultation (February 21, 2006) emergency attention was required. Observed: facial edema and persistent fever $\left(38.6^{\circ} \mathrm{C}\right)$. Body weight was increased by $2.0 \mathrm{~kg}$ (edema). Urinalysis, normal. Hospitalization in Itaporanga: diagnostic hypotheses, nephritis and bronchopneumonia. Chest radiography showed progressive enlargement of the cardiac area. Hemogram: moderate anemia without leukocytosis. According to the laboratory examinations, renal function was normal: $\mathrm{BUN}=19.0 \mathrm{mg} / \mathrm{dL}$; creatinine $=0.6 \mathrm{mg} / \mathrm{dL}$. Antistreptolysin $\mathrm{O}$ titer $(\mathrm{ASO})=800 \mathrm{UI} / \mathrm{mL}($ negative $<299 \mathrm{UI} / \mathrm{mL})$. Three days afterwards (February $24^{\text {th }}, 2006$ ): urinalysis, normal. BUN increased to $23.2 \mathrm{mg} / \mathrm{dL}$; creatinine, $0.7 \mathrm{mg} / \mathrm{dL}$ (still within normal limits). The patient was transferred to the Santa Casa hospital in Avaré. Here, laboratory test results diverged from those previously obtained elsewhere. Now severe anemia $(\mathrm{Hb}=9.1 \mathrm{~g} / \mathrm{dL})$ and left shift leukocytosis $\left(18600 / \mathrm{mm}^{3}\right)$ (9.0\%) were detected. Diagnosis: pneumonia with pleural effusion and respiratory failure. Abdominal pain increased in intensity; the hypothesis of acute abdomen was formulated. Chest radiography: interstitial opacity of the right lung base (paracardiac), homogeneous opacity of the right lung base (pleural effusion), accentuation of the right lung hilum, and enlargement of the cardiac area. A routine radiography of the abdomen showed a normal aspect of bone structures, anatomical images preserved, intestinal gases distributed as usual and no pathological calcifications observed, the hypothesis of acute abdomen was ruled out.

On February $25^{\text {th }}$, 2006: thoracic fluid drainage (thoracentesis) on the right side. No acid-fast or other bacilli were found in the pleural fluid. Oxacillin, Amicacin and Ceftriaxone were prescribed. On this day, the X-ray picture showed small subcutaneous emphysema and a thoracic tube on the right side; interstitial opacity on the right lung base and enlarged cardiac area. Laboratory test results on February $26^{\text {th }}, 2006$ showed: creatinine $=0.8 \mathrm{mg} / \mathrm{dL} ; \mathrm{BUN}=26 \mathrm{mg} / \mathrm{dL}$; total serum protein $=4.2 \mathrm{~g} / \mathrm{dL} ;$ serum albumin $=1.7 \mathrm{~g} / \mathrm{dL} ;$ serum globulin $=2.5 \mathrm{~g} / \mathrm{dL}$; $\mathrm{A} / \mathrm{G}$ ratio $=0.7$; amylase $=11 \mathrm{U} / \mathrm{L}$. According to the nurse's report, the patient had diarrhea and oliguria; the pleural fluid was "purulent". On the following day his condition worsened: he had oliguria and dyspnea, was anorectic, crying and moaning with intense abdominal pain. On February $28^{\text {th }}, 2006$, the patient's condition was declared critical, he was transferred to the Hospital das Clínicas da Faculdade de Medicina de Botucatu - Universidade Estadual Paulista - UNESP, where hypotension was observed $\left(\mathrm{P}_{\text {sys }}=90 \mathrm{~mm} \mathrm{Hg} ; \mathrm{P}_{\text {dias }}=60 \mathrm{~mm} \mathrm{Hg}\right)$.

Cultures of pleural fluid, blood, urine, and feces showed negative results. March 2 ${ }^{\text {nd }}, 2006$ : the echocardiogram showed slight hypertrophy and moderate systolic dysfunction of the left ventricle (LV); pericardial effusion and moderate to serious mitral insufficiency. Treatment for heart failure was started. An investigation was initiated into the etiology of the myocarditis. The child was pronounced dead on March $7^{\text {th }}, 2006,27$ days after the first consultation.

Necroscopical examination established the diagnosis of ACD. Consequential causes: cardiomegaly, pleural effusion, ascitis $(200 \mathrm{~mL}$, citrine-yellow), chronic passive pulmonary congestion. Terminal cause: heart failure. Serological tests (ELISA and passive hemagglutination for the diagnosis of ACD) performed postmortem (on March $14^{\text {th }}$, 2006) were positive. The results of the same tests, applied to relatives of the patient (mother, father, grandmother, and two brothers) were negative. Heart histological sections showed T. cruzi amastigote "nests", inflammatory mononuclear infiltrate and sparse granulomatous structures in the interstitial spaces. The cardiac fibers showed diffuse alteration, vascular congestion interstitial and interfibrillar edema; agglomeration of amastigotes. Mononuclear infiltration, mainly composed of lymphocytes and plasma cells. Myofibers, predominantly dissociated were observed

2. Epidemiological investigation: Our epidemiological investigation included domiciliary visits to the relatives of the deceased patient. According to them, he was delivered normally in a hospital maternity ward. His height and weight had been normal for his age and he was periodically examined at a public Health Center in the municipality, regularly receiving milk. There were no records of past illness, blood transfusion or hospitalization. 


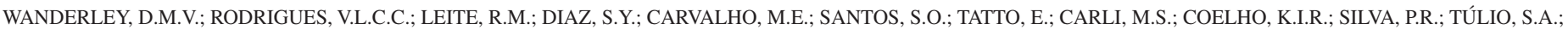

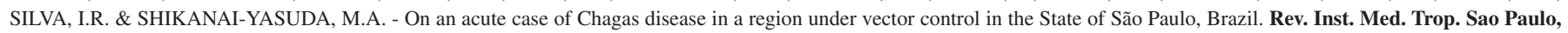
52(3):151-6, 2010

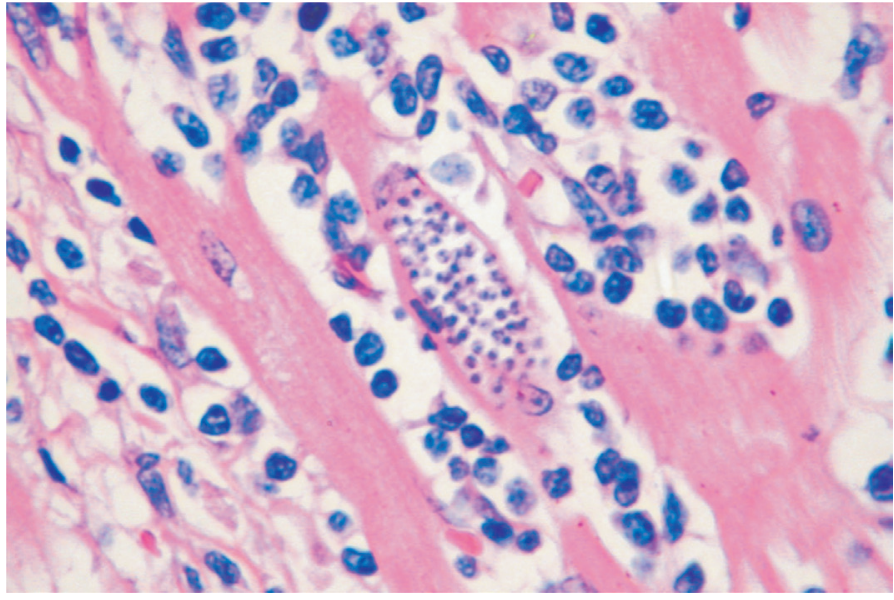

Fig. 1 - Intracellular Trypanosoma cruzi (amastigota "nest") inside myocardial fibers. Inflammatory reaction.

His family had been living for seven months in a wooden house with poor standards of hygiene and frequent contact with animals in its periphery. It was impoverished and dysfunctional (a chronically alcoholic father and a mother suffering from depression). In addition to the deceased, his parents and two brothers, aged one and seven, occupied the family house. They had previously lived on a farm in the municipality of Salto de Pirapora. No records of blood transfusion or hospitalization of this patient could be found in the Health Centers of Salto de Pirapora or Votorantim, which his family had access to.

As stated by the deceased patient's father, a "barbeiro" ("conenosed bug", Hemiptera: Reduviidae), which had fallen from the roof of the family house during the day, was captured at the beginning of February, 2006, and duly notified to the health authorities on February $20^{\text {th }}, 2006$. According to the patient's mother, she had, less than 30 days earlier, captured another "barbeiro" specimen in his bed. That insect was eventually destroyed. In spite of his age, the boy still sucked a pacifier and remained frequently in bed for long periods and complained of leg pain. He liked to eat raw vegetables, but had been losing his appetite for about a year, was rather aggressive, introverted, and easily tired when playing with other children. His grandfather died of CD more than 20 years ago and one of his uncles has also been infected.

Xenodiagnosis was applied to three members of the family (with the exception of the one-year-old child) which came out negative.

A nationwide serologic survey is now applied to children five-yearsold or younger in the state of São Paulo. It includes the municipality of Itaporanga. One of the localities selected is in the proximity of that where the family of the deceased patient lived. From a sample of 356 sera, none produced positive results (personal communication, Prof. Alejandro O. Luquetti-UFGO, Goiânia, GO, Brazil).

3. Entomological investigation: The triatomine specimen captured by the deceased boy's family and notified to the local health authorities on February $20^{\text {th }}$, 2006, was identified as Panstrongylus megistus, negative for T. cruzi. A consequence of this finding was an exhaustive search for triatomines inside the house and in the surrounding area; no triatomines were found.
The family house is made of wooden planks (Fig. 2), and has marks of the permanence of such domestic animals as poultry, ducks, pigs, dogs, and cows in its periphery, where their feces accumulated. Inside the house mice tracks were visible. The family declared that, after the death of their child, the Social Promotion Sector of the Municipality assisted them in cleaning the house and clearing the surrounds of weeds. They have also sprayed insecticides as recommended. A new exhaustive entomological investigation included spraying the house with alphaCypermethrin preceded by the application of a dislodging agent (Pirisa). Another investigation was made in this area after a period of three months. Light traps were set up to capture triatomines in the surrounds of a house where the deceased boy's family had stayed for about 30 days during the month of August 2005. No triatomines were found.

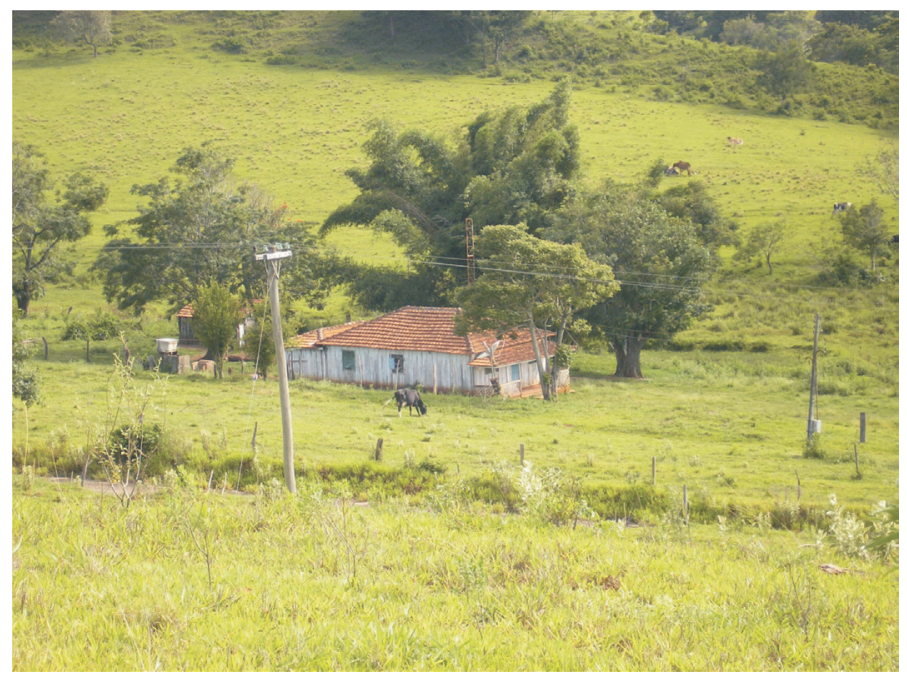

Fig. 2 - Home of the deceased ACD patient, in the rural zone of Itaporanga, SP, Brazil

4. Situation of the entomological surveillance for Chagas disease in the municipality of Itaporanga, state of São Paulo: The municipality of Itaporanga is located in the Southwest of the state of São Paulo, Brazil (2342'24'S, 49²9'24'W). It is included in the Governmental Region of Avaré (an administrative subdivision of the state), in the homogeneous Micro-Region of Campos de Itapetininga, a subdivision of the former. Five infected specimens of Triatoma infestans had been captured here in the year 1978, while the last capture of T. infestans (one specimen) in the Municipality of Itaporanga dates back to 1974. Since then, very few specimens of $P$. megistus have been found in human domiciles, some of them naturally infected. During the 1980s, triatomine infestation reached extremely low levels in Itaporanga. The year 1988 marked the last extensive search for triatomines in houses and their surroundings. Not a single specimen was captured during that year. Since then, entomological surveillance has been maintained by encouraging local people to notify the health authority or the local school, of the presence of any insect suspected of being a "barbeiro". It should be emphasized that, in the locality where the deceased patient had his residence, the capture of a female specimen of $P$. megistus (negative for $T$. cruzi infection) had been notified. On March 8, 2006 the consequent search for triatomines was negative. No triatomine species were found.

From the year 2000 onwards, P. megistus has been the only species captured in the municipality of Itaporanga (95.2\% inside houses), 


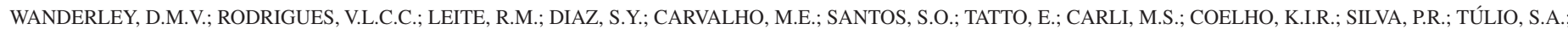
SILVA, I.R. \& SHIKANAI-YASUDA, M.A. - On an acute case of Chagas disease in a region under vector control in the State of São Paulo, Brazil. Rev. Inst. Med. Trop. Sao Paulo, 52(3):151-6, 2010

infected (15.5\%); these have been isolated specimens, without formation of colonies (Table 1).

Table 1

Triatomine capture in the municipality of Itaporanga, SP, Brazil, from 2000 to 2006

\begin{tabular}{lcccc}
\hline YEAR & \multicolumn{2}{c}{$\begin{array}{c}\text { Panstrongylus megistus } \\
\text { collected }\end{array}$} & \multicolumn{2}{c}{$\begin{array}{c}\text { Panstrongylus megistus } \\
\text { infected }\end{array}$} \\
\cline { 2 - 5 } & Intra & Peri & Intra & Peri \\
\hline 2000 & 12 & - & 1 & - \\
2001 & 9 & - & 1 & - \\
2002 & 14 & 2 & 5 & - \\
2003 & 19 & - & 3 & - \\
2004 & 8 & - & 1 & - \\
2005 & 8 & 1 & 1 & - \\
2006 & 14 & 1 & 1 & - \\
\hline
\end{tabular}

Source: SUCEN/DCV/NIT, 2009.

The two triatomine specimens captured inside houses during the period from 2001 to 2003 had precipitin tests positive for human blood. Those specimens captured more recently had only bird and dog blood identified as ingested. According to the entomological norms in force at that occasion in the Control Program of Chagas disease - Programa de Controle da Doença de Chagas - PCDCh, all the residents of a house where an infected triatomine had been captured should undergo serological tests for T. cruzi infection, to ascertain the consequences of the occurrence of infected vectors in a human dwelling. Serological tests of the inhabitants of the municipality of Itaporanga, during the periods from 1984 to 1988 and from 1990 to 1993, showed a total of $12.06 \%$ positive results. Remarkably, none of the positive tests were observed in people aged 15 years or younger ${ }^{2}$. The serological data in the later years 2001 and 2002, consisted of, respectively, six and 10 blood samples and one seropositive in each year, both belonging to the age group 51 to 60 years.

5. Reservoir investigation: Before spraying the place with dislodging agents, a comprehensive investigation into the possible occurrence of vertebrate animal reservoirs was made in the area. Traps were installed for the capture of wild animals known to be potential reservoirs of T. cruzi. This resulted in the capture of two specimens of Didelphis albiventris. Fresh and stained blood smears, in addition to xenodiagnosis, were all negative for flagellate forms of T. cruzi. A specimen of Rattus rattus was shown to be positive for Trypanosoma (Herpetosoma) lewisi, observed in fresh blood smears. This protozoon strain was isolated by inoculation in laboratory mice (Wistar).

6. General orientation: The Health Service personnel were instructed to keep a record of every bit of information about cases of fever in the families when collecting insects reported by householders of Itaporanga inhabitants. Notifiers were told to be alert to the emergence of symptoms (especially fever) in any member of their families during the 90 days following notification. Furthermore, they should look for medical service and make known the discovery of blood-sucking insect/s in their homes.

\section{DISCUSSION}

Following the Control Program of the State of São Paulo (PCDCh) norms, the specific duties under the responsibility of SUCEN should be aimed at the control of vector triatomines. Upon the detection of $T$. infestans specimens in the human domicile, a serological investigation of the local residents should be made. Regarding the occurrence of other vector species, this investigation will depend only on the indoor detection of vectors with ingesta identified as human blood and infected with T. cruzi. In the high plateau of the state of São Paulo, as a whole, no reagent cases have been found among young people ${ }^{4}$, considering the current conditions for performing serological tests in population samples. The same is not true for the littoral ${ }^{5}$. In the neighborhood of Itaporanga $\mathrm{CD}$ was still prevalent in the six years or over age group in 1976. This explains the concern for diagnosing congenital CD infection in the female seroreagent group ${ }^{3}$.

Serological tests for CD applied to the inhabitants of Itaporanga between the years 1976 and 1978 produced $19.22 \%$ positives - confidence interval $95 \%$ of the positives $=17.27$ to 21.34 out of a total of 1,441 samples from four localities ${ }^{2}$. In the 2-to-29-year-old age-group $42.23 \%$ of the cases are clustered, which indicates a problem of CD transmission in this area. It is important to note that Itaporanga was included in the project of serological survey among school-children in the first series of the fundamental classes. That survey, made between 1973 and 1983, comprised 54 municipalities of different regions of the state of São Paulo. The proportions of positives were $14.0 \%$ and 8.4\% in 1973 and 1974 respectively, and decreased with the passage of time until they reached the values of $0.9 \%$ and zero per cent in 1982 and 1983, respectively ${ }^{2}$.

In Itaporanga, seroreactivity results have now reached values comparable to those characteristic of past infection, in spite of the fact that infected $P$. megistus specimens have been observed. The occurrence of this species infected with $T$. cruzi has been detected ${ }^{6}$; thus, vigilance is maintained in many areas of the state ${ }^{13}$. On every occasion that an insect is notified, SUCEN promotes cautious observation of the area mentioned, (attendance to notification) in search of vector foci and colonies ${ }^{11}$.

In spite of all caution we were compelled to report the occurrence of an ACD case in the state of São Paulo, Brazil: a previously healthy sixyear-old child, resident in the rural zone of Itaporanga, manifested clinical signs and symptoms compatible with those of ACD, such as continuous fever, leg and face edema, intense abdominal pain, myocardiopathy, and eventually heart failure.

As the semiological techniques used failed to identify the etiology of the disease, the patient did not receive the specific treatment. The etiological diagnosis of this case was the result of postmortem histopathological and parasitological examinations performed at least 27 days after the first medical consultation.

Probable contact with the triatomine specimen found by the patient's mother on his bed (destroyed without having been examined), could possibly have caused the infection through his eyelid mucosa or small quantities of triatomine excreta might have been ingested, accepting the hypothesis that the insect was, in fact, infected. According to estimates of incubation periods of Chagas disease (three to 22 days for oral transmission, and five to 15 days for vectorial transmission), contact 


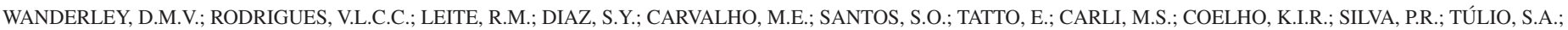

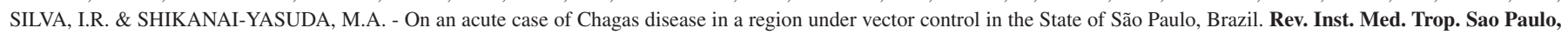
52(3):151-6, 2010.

with the triatomine specimen which was notified could have caused the infection. However, in this case the route of infection of T. cruzi would be difficult to trace. Vectorial transmission should not be ruled out altogether, as an infected specimen of $P$. megistus had been captured in the municipality of Itaporanga in the year 2006. However, this hypothesis is based on the slimmest evidence. The hypothesis of oral contamination was considered remote as the other members of the patient's family, who shared the same sources of nutrients (father, mother, and brothers), were not demonstrated to be infected.

This case history exposes the difficulty that a clinician may experience in trying to act promptly to diagnose a case of ACD, even in the environment of a tertiary-level hospital. Recent and well documented outbreaks of trypanosomiasis resulting from oral contamination, exhibited some manifestations which until recently would have been considered unusual. It is evidently necessary to adopt new definitions for suspected cases of ACD to enable clinicians to reach without delay the correct diagnosis, so that the specific treatment can be promptly started.

In addition to the classic definitions of the acute disease ${ }^{1}$, fever persisting for more than five days, adenomegaly with hepatosplenomegaly, bilateral edema of the eyelids, edema of the extremities, exanthema, myocarditis and meningoencephalitis, the inclusion of such signs as suspected glomerulonephritis with a normal urinary sediment, pericarditis, cardiac failure with or without pleural effusion, icterus without apparent cause, associated with fever; anasarca without urinary or cardiac dysfunction, associated with fever; fever without any apparent focus in patients with such positive epidemiological data as direct contact with triatomines or with food contaminated with their excreta should be investigated.

Although associated with a great number of symptoms, ACD has not been a diagnostic hypothesis as frequently as should be reasonably expected. Now, the most important vector of $\mathrm{CD}$ is under control in $\mathrm{Brazil}^{8}$, but there have been many recent reports of probable oral transmission. The acute phase of $\mathrm{CD}$ is characterized by very high concentrations of trypomastigotes in the peripheral blood. Thus, the live parasite is readily identified in fresh blood samples. This is a simple, efficient, rapid and inexpensive means, highly recommended for the identification of the etiological agent of CD. In case of positive result, immediate specific treatment should be prescribed. This case history emphasizes the importance of the maintenance of the program of active surveillance and the inclusion of areas where the vector is already under control. We suggest the creation of two levels of control. Level One: control of triatomines, which will count upon the cooperation of the community and surveillance institutions; selection of techniques sensitive enough to detect new, scarcely evident triatomine colonies. Immediate notification of positive cases to the Health Units. Level Two: training of Health Teams should be adequately updated to permit a prompt identification of suspected cases of ACD, even when the patients are coming from a region where the vector control has been considered successful for the last decades. We aim to avoid misdiagnosis and the worsening of a patient's condition towards an otherwise avoidable death.

\section{AUTHOR CONTRIBUTIONS}

Dalva Marli V. Wanderley: first draft of the manuscript, supervision of field surveillance and control of CD vector activity, text writing; Vera
Lúcia C.C. Rodrigues: field supervision of vector triatomine control and potential vertebrate $T$. cruzi reservoirs, in addition to laboratory work, $T$. cruzi detection and histopathological identification; Ruth M. Leite, Kunie I. R. Coelho and Sueli Y. Diaz: support for the epidemiological as well as entomological surveillance work in the Region of Sorocaba, where the case under study occurred; Maria Esther de Carvalho: execution of serological tests, analysis of laboratory data concerning the epidemiological history of the area under study; Soraya O. Santos, Érica Tatto and Maria Salete Carli: epidemiological investigation support in the XVI Botucatu Health Division; Paulo Ribeiro da Silva and Sandra Aparecida Túlio: epidemiological investigation support in Avaré, Isaias Ribeiro da Silva and Maria A Shikanai-Yasuda: clinical investigation and text writing.

\section{RESUMO}

\section{Sobre caso de doença de Chagas aguda em região de vetores controlados no Estado de São Paulo, Brasil}

Desde a década de 1970 não se notificavam casos autóctones de doença de Chagas aguda em São Paulo. Em março de 2006 a Vigilância Epidemiológica registrou óbito por doença de Chagas aguda, em Itaporanga, de paciente de seis anos de idade. Exame histopatológico post mortem realizado no Hospital das Clínicas da Faculdade de Medicina de Botucatu confirmou o diagnóstico. Consultamos prontuários de hospitais e entrevistamos profissionais de saúde envolvidos além de familiares do paciente. Descrevemos medidas adotadas in loco para identificar a via de transmissão, reservatórios e vetores. Discutimos as possíveis fontes de infecção. Na região não foram identificados outros casos humanos, vetores ou reservatórios vertebrados infectados por Trypanosoma cruzi. Salientamos a importância de manter a vigilância, mesmo em áreas onde a transmissão de doença de Chagas está interrompida e naquelas ainda infestadas por triatomíneos. Deve-se admitir a hipótese diagnóstica de doença de Chagas quando observados: edema palpebral (uni ou bilateral), insuficiência cardíaca, miocardite, pericardite, anasarca, quadros similares aos de síndrome nefrótica ou glomerulonefrite sem causas outras aparentes, em pacientes com dados epidemiológicos positivos. Encontro, mesmo em raras ocasiões, de triatomíneos na região ou ainda contato com alimento contaminável com formas infectantes de T. cruzi.

\section{REFERENCES}

1. Amato Neto V, Shikanai-Yasuda MA, Sabbaga Amato V. Doença de Chagas aguda. In: Dias JCP, Coura JR, orgs. Clínica e terapêutica da doença de Chagas: uma abordagem prática para o clínico geral. Rio de Janeiro: Fiocruz; 1997. p. 227-34.

2. Carvalho ME. Sorologia da infecção chagásica no Programa de Controle do Estado de São Paulo, Brasil. [Tese]. São Paulo: Universidade de São Paulo, Faculdade de Saúde Pública; 2000.

3. Carvalho ME, Latorre MRDO, Ferreira CS, Mello CS, Barata JMS. Soroprevalência de infecção chagásica em área de Triatoma infestans após medidas de controle. Rev Saúde Pública. 2000;34:15-20.

4. Carvalho ME, Silva RA, Rodrigues VLCC, Oliveira CD. Programa de Controle da Doença de Chagas no Estado de São Paulo: sorologia de moradores como parte de investigação de unidades domiciliares com presença de triatomíneos vetores na década de 1990. Cad Saúde Pública. 2002;18:1695-703.

5. Carvalho ME, Silva RA, Barata JMS, Domingos MF, Ciaravolo RMC, Zacharias F Soroepidemiologia de tripanosomíase americana na região do litoral sul, São Paulo. Rev Saúde Pública. 2003;37:49-58 
WANDERLEY, D.M.V.; RODRIGUES, V.L.C.C.; LEITE, R.M.; DIAZ, S.Y.; CARVALHO, M.E.; SANTOS, S.O.; TATTO, E.; CARLI, M.S.; COELHO, K.I.R.; SILVA, P.R.; TÚLIO, S.A.; SILVA, I.R. \& SHIKANAI-YASUDA, M.A. - On an acute case of Chagas disease in a region under vector control in the State of São Paulo, Brazil. Rev. Inst. Med. Trop. Sao Paulo, 52(3):151-6, 2010.

6. Nascimento C, Marassá AM, Curado I, Piazza RMF. Encontro de Panstrongylus megistus em ecótopo artificial: domiciliação ou mera visitação? Rev Soc Bras Med Trop. 1997;30:333-6.

7. Noireau F, Abad-Franch F, Valente SA, Dias-Lima A, Lopes CM, Cunha V, et al. Trapping Triatominae in sylvatic habitats. Mem Inst Oswaldo Cruz. 2002;97:61-3.

8. Organización Panamericama de la Salud. OPS/HDM/CD. XV Reunión de la Comisión Intergubernamental del Cono Sur para la eliminación de Triatoma infestans y la interrupción de la transmisión de la tripanosomiasis transfusional. Validación de la interrupción de la transmisión vectorial de Trypanosoma cruzi por T. infestans en Brasil. Brasília; 2006.

9. Rocha e Silva E, Guarita OF, Ishihata GK. Doença de Chagas: atividades de controle dos transmissores no Estado de São Paulo, Brasil. Rev Bras Malariol. 1979;31:99-119.
10. Rocha e Silva EO, Rodrigues VLCC, Reyes S. Manual de normas sobre organização e funcionamento de laboratórios de diagnóstico da doença de Chagas. Brasília: Ministério da Saúde; 1980.

11. Secretaria de Estado da Saúde de São Paulo. Superintendência de Controle de Endemias. Vigilância entomológica da doença de Chagas no Estado de São Paulo. Diretrizes Técnicas. São Paulo; 2003.

12. Siqueira AF. Estudos sobre a reação de precipitina aplicada na identificação do sangue ingerido por triatomíneos. Rev Inst Med Trop Sao Paulo. 1960;2:41-53.

13. Wanderley DMV, Silva RA, Carvalho ME, Barbosa GL. Doença de Chagas: a vigilância entomológica no Estado de São Paulo. Bol Epidemiol Paulista. 2007;4(38):10-14

Received: 27 March 2009

Accepted: 8 March 2010 